\title{
Information technology in ophthalmology
}

Ophthalmology and its adnexal disciplines are in the grip of an explosion in information technology (IT), as are most branches of medicine. Not only do we have a bewildering number of published (on paper that is) periodicals, textbooks, and society (or faculty or college) newsletters to sift, select, and assimilate information from, but we now also have an increasing array of electronic sources of information.

Many peer reviewed journals (the $B F O$ included) are now represented on the internet in world wide web ("web") sites. ${ }^{1}$ Some of these contain full text and graphics articles whereas others offer samples of their content, or tables of contents. Inevitably, they almost always provide subscription information. Most usefully, the web sites usually provide the current instructions for authors. The internet addresses (uniform resource locators, URLs) of some ophthalmology journals are provided in Table 1.

In addition to formal "publications", there are many web sites which contain information that has not undergone peer review. Some of these web sites offer information about well established societies, faculties, or colleges. Examples of these are provided in Table 2. Others are sites of specific hospitals, laboratories, and even individual practitioners. These latter web sites are often advertisements for the services of the organisation or individual who runs the site and, as such, are publicity ventures and not necessarily rich or reliable sources of information. Web sites which are advertisements and publicity ventures for biomedical publishers, manufacturers, and traders also exist in abundance. The true nature of a web site is often not apparent until time has been expended, or wasted, in finding it and reading it.

A further type of site that can be very useful also exists. This type of site has collected information from many disparate sources, presents them in a digestible format, and provides links to more information as a starting point for

Table 1 Addresses of web sites of ophthalmology journals

\begin{tabular}{|c|c|}
\hline fournal & $U R L$ \\
\hline Am f Ophthalmol & http://www.ajo.com \\
\hline Am Orthoptic $\mathcal{F}$ & http://www.aoj.org/ \\
\hline Arch Ophthalmol & $\begin{array}{l}\text { http://www.ama-assn.org/public/journals/ } \\
\text { opht/opht home.htm }\end{array}$ \\
\hline Brf Ophthalmol & http://www.bjophthalmol.com \\
\hline Curr Eye Res & http://www.oup.co.uk/cureye/ \\
\hline Digital f Ophthalmol & $\begin{array}{l}\text { http://www.meei.harvard.edu/meei/ } \\
\text { DJOhome.html }\end{array}$ \\
\hline Graefes Arch Clin Exp Ophthalmol & http://link.springer.de \\
\hline Internet $\mathcal{F}$ Ophthalmol & http://phobos.unich.it/injo/index.html \\
\hline Invest Ophthalmol Vis Sci & http://www.faseb.org/arvo/iovs.htm \\
\hline F Pediatr Ophthalmol Strabismus & $\begin{array}{l}\text { http://www.slackinc.com/eye/jpos/ } \\
\text { jposmast.htm }\end{array}$ \\
\hline $\mathcal{F}$ Refract Surg & $\begin{array}{l}\text { http://www.slackinc.com/eye/jrs/ } \\
\text { jrshome.htm }\end{array}$ \\
\hline Molecular Vision & http://www.emory.edu/molvis/ \\
\hline Ocular Immunol Inflamm & http://www.knaw.nl/ioi/ocular/ \\
\hline Ophthalmology & http://www.eyenet.org/ophthalmology \\
\hline Prog Retinal and Eye Res & http://www.elsevier.nl/locate/preteyeres \\
\hline Retina $\mathcal{F}$ & http://www.retinajournal.com/ \\
\hline Surv Ophthalmol & http://www.elsevier.nl/locate/survophthal \\
\hline
\end{tabular}

Table 2 Addresses of web sites of ophthalmology societies, colleges, etc

\begin{tabular}{|c|c|}
\hline Organisation & URL \\
\hline $\begin{array}{l}\text { American Academy of } \\
\text { Ophthalmology (AAO) }\end{array}$ & $\begin{array}{l}\text { http://www.eyenet.org/ } \\
\text { alt_aao_index.html }\end{array}$ \\
\hline American Academy of Optometry & http://www.aaopt.org/ \\
\hline $\begin{array}{l}\text { American Association for Pediatric } \\
\text { Ophthalmology and Strabismus } \\
\text { (AAPOS) }\end{array}$ & http://www.med-aaops.bu.edu/ \\
\hline $\begin{array}{l}\text { American Society of Cataract and } \\
\text { Refractive Surgery (ASCRS) }\end{array}$ & http://www.ascrs.org/ \\
\hline $\begin{array}{l}\text { Association for Research in Vision } \\
\text { and Ophthalmology (ARVO) }\end{array}$ & http://www.faseb.org/arvo/ \\
\hline Canadian Ophthalmological Society & http://www.eyesite.ca/ \\
\hline $\begin{array}{l}\text { Contact Lens Association of } \\
\text { Ophthalmologists, Inc (CLAO) }\end{array}$ & http://www.clao.org/ \\
\hline $\begin{array}{l}\text { European Ophthalmic Pathology } \\
\text { Society (EOPS) }\end{array}$ & $\begin{array}{l}\text { http://www.helsinki.fi/laak/silk/perus/ } \\
\text { eopshome.html }\end{array}$ \\
\hline $\begin{array}{l}\text { German Ophthalmological } \\
\text { Association }\end{array}$ & http://www.dog.org/ \\
\hline International Glaucoma Association & http://www.iga.org.uk/iga/ \\
\hline $\begin{array}{l}\text { North American } \\
\text { Neuro-Ophthalmology Society. }\end{array}$ & $\begin{array}{l}\text { http://www.access.digex.net/ pcalvert } \\
\text { nanosnet.htm }\end{array}$ \\
\hline Ophthalmic Oncology Group & $\begin{array}{l}\text { http://www.helsinki.fi/laak/silk/oog/ } \\
\text { ooghome.html }\end{array}$ \\
\hline $\begin{array}{l}\text { Royal Australian College of } \\
\text { Ophthalmologists }\end{array}$ & $\begin{array}{l}\text { http://www.raco.org.au/open/ } \\
\text { home.htm }\end{array}$ \\
\hline $\begin{array}{l}\text { American Society of Ophthalmic } \\
\text { Plastic and Reconstructive Surgery } \\
\text { (ASOPRS) }\end{array}$ & http://www.asoprs.org/ \\
\hline International Society for Eye Research & http://www.iser.org/ \\
\hline $\begin{array}{l}\text { International Society of Online } \\
\text { Ophthalmologists }\end{array}$ & http://www.isoo.org/ \\
\hline Verhoeff Society & $\begin{array}{l}\text { http://pathology.mc.duke.edu/ } \\
\text { EyePath/vs.htm }\end{array}$ \\
\hline
\end{tabular}

the inquisitive. Web sites of this nature are found within the internet presence of some of the organisations listed in Table 2. Of these, the web site of the American Association of Ophthalmology is particularly useful in its "eye care links" section (URL: http://www.eyenet.org/eyelinks.html) which allows the viewer to search for information on a range of topic headings including mailing lists, national organisations and societies, patient information, physician resources, publications and journals, and more. Sites with a similar ethos, although less elaborate in presentation, are also maintained by individuals on a philanthropic basis. These include a web site on ophthalmic pathology (URL: http://pathology.mc.duke.edu/EyePath/EyePath.htm) and a web site aimed at UK ophthalmic trainees (URL: http:// www.wp.com/ophthalmology).

The technology of the internet also provides the ability to search large databases for published information using online bibliographical databases ${ }^{23}$ (such as Medline, Embase, and Pubmed). Bibliographical data downloaded can then be handled by personalised, commercial, or customised bibliography programmes to manage the data on your personal computer. ${ }^{3}$ Online databases also exist covering other aspects of biomedicine such as molecular biological and genetic sequence data. The internet has also been used specifically to compile a database of ophthalmological practice and, in the process, it has been used a research tool. ${ }^{4}$ 
Table 3 Details of ophthalmology related email discussion groups

\begin{tabular}{|c|c|c|}
\hline List name* & Description & Further information \\
\hline CorneaRefSurg & Refractive surgery list. Restricted and moderated & CorneaRefSurg@eyecenter.ucsd.edu \\
\hline CVNet & Colour and vision network & cvnet@skivs.org \\
\hline EYEMOV-L & Eye movement discussion list. Open enrolment & eyemov-r@spcvxa.spc.edu \\
\hline Eyepathology & Ophthalmic pathology list. All aspects of diagnosis and research. Restricted & http://www.mailbase.ac.uk/lists/eyepathology/ \\
\hline EYEPLAST & Oculoplastics list. Restricted and moderated & gweinstn@pop.pitt.edu \\
\hline Glaucoma-Net & Glaucoma list. Restricted and moderated & weinreb@eyecenter.ucsd.edu \\
\hline Kera-Net & Cornea list. Restricted and moderated & listproc@ucdavis.edu \\
\hline LensNet & $\begin{array}{l}\text { Database of researchers specialising in lens and/or cataract research at both the basic } \\
\text { science and clinical level }\end{array}$ & LensNet@vt.edu \\
\hline OPHTHAL & $\begin{array}{l}\text { Clinical ophthalmology discussion group. Restricted and moderated. } 520 \text { members from } \\
29 \text { countries }\end{array}$ & $\begin{array}{l}\text { http://www.netspace.org/cgi-bin/lwga } \\
\text { te?execute=about\&list=OPHTHAL }\end{array}$ \\
\hline OPRS-NET & Plastics list. Restricted and moderated & kikkawa@eyecenter.ucsd.edu \\
\hline RETINA-NET & Retina list. Open and moderated & joinretina@vision.eei.upmc.edu \\
\hline RPLIST & Retinitis pigmentosa and other degenerative retinal diseases list. Open list & listserv@SJUVM.STJOHNS.EDU \\
\hline
\end{tabular}

*How to subscribe to a list.

For lists with email addresses shown: send a message to the address listed using the list's name (for example, "abcd-1"). Include your name and the word "subscribe", abbreviated as "sub", in the body of the message, not in the message header. Omit message signatures. It should look like this: sub abcd-1 your name.

For lists with web site URLs shown: visit the web site and follow instructions.

A further aspect of the internet, which is potentially useful for even the busiest professional, is the email discussion group (or "list" as they are known). Discussion groups offer simultaneous contact with many professionals in the discipline, through a single email address, allowing contact with individuals without prior knowledge of their interests, skills, or even their personal email address. The nature of the message can be very varied. Email discussion groups enable participants to consult on and discuss diagnostic problems with colleagues with special expertise; discuss the availability of patients, tissues, cells, DNA, etc for research; distribute material such as papers, minutes, reports, and data; advertise posts and fellowships; publicise conferences and seminars. As email does not interrupt work, unlike a phone call which must be answered or a meeting or videoconference which must be "attended", it can be consulted at a convenient time. A personal secretary can handle email on a daily basis as with conventional (paper) mail and new messages or replies can be dictated for typing in the normal fashion. Successful email discussion groups exist in many areas of medicine and science and there is great potential for such groups in ophthalmology. Several groups do exist, such as the recently formed eyepathology group, covering a wide range of topic areas (Table 3 ).

Of course, the internet and its perplexing range of possibilities is not the only aspect of IT to confront us. For years now we have been using pagers, messaging services, and mobile phones. Many of us have now tried textbooks or journals in CD-ROM format and most hospital libraries have facilities for bibliographical searches of, for example, Medline on CD-ROM. Journals are increasingly including reviews of multimedia publications among their book reviews. In clinical practice, we are taking patient photographs with digital cameras, the radiologists are giving opinions on computed tomograph or magnetic resonance imaging scans transmitted digitally down lines, and the records department is replacing your personal secretary with a computer with voice recognition software for the dictation of letters. Those preparing or reviewing contributions for journals or books are dealing with illustrations which have undergone digital image enhancement. Indeed, some journals demand the inclusion of original unenhanced pictures for review purposes. Publishers are increasingly requesting manuscript contributions directly on magnetic media such as floppy disc or zip disk.

So is this abundance of IT good for you? There is no doubt that much of these advances are potential time savers, but all too often we find them to be time wasters. The technology is such that both the hardware and software applications have steep learning curves despite media pub- licity to the contrary. This is confounded by the frequent refreshers required because of the constantly evolving nature of hardware and software. Changes to the machinery and programs lead to problems with compatibility with colleagues, home and office computers, your secretary's computer, and those of your local medical illustration department or publisher. Frequent upgrading of computing capabilities leads to obsolescence of hardware and software with the attendant cost implications and redundancy or retraining of staff. However, the most critical problem some people experience is that the capabilities brought by modern IT lead to information overload in their already busy lives. This discourages some from wholeheartedly embracing the technology. For example, a search for internet sites using the phrase "ophthalmology" turns up around 10000 "hits"- this is more likely to hinder than to help.

There are, of course, problems more specific to the medical use of IT. For example, how do you ensure confidentiality when using email to discuss a case with a colleague? Encryption technology may offer the key to this problem. What are the medicolegal issues involved in using electronic consults? How do we control the quality of information supplied electronically? This is particularly problematic if we forget that much of what appears on the internet has not undergone peer review or any form of moderation. The likelihood that electronic databases, such as bibliographical databases, are not comprehensive must be remembered. How do we ensure that we do not become victims of automated direct marketing via our computer (which can lead to a form of system overload known as "spamming")?

Despite these drawbacks there are enormous potential benefits, not least the sheer volume of information available if we know how to harness it. Electronic mail, in addition to its use for discussion, can be used for rapid communication of discharge letters, laboratory reports, or consultation requests, for example. ${ }^{5}$ One potential use of email is that it may become a method for holding electronic conferences of peers with discussion available to all participants. Unlike a conventional conference, which requires funding and the attendance of many hundreds to be worthwhile, valuable information can be obtained through an email discussion list of appropriate collaborators. This is especially so in conjunction with associated documents or pictures made available on the world wide web. We are all aware of the contribution of IT to enhance the presentation of data, be this in publications, theses, teaching material, or verbal presentations at conferences. It allows us an air of professionalism more commonly encountered in commerce. It is clear that remote access to databases will help efficient use of time and resources. 
Consider the missing test result from the case record, has it been done, should it be repeated? Access to the laboratory database from the office desktop computer can resolve this quandary.

Inevitably, the future of medical IT is hard to predicteven Bill Gates (head of Microsoft) can only speculate. Medicine will probably continue its efforts to catch up to industry levels of IT use. Electronic mail is likely to remain solid, as it is the lowest common denominator of the internet and the only method of electronic communication likely to be available in most parts of the world. Technologically, there is likely to be a streamlining and convergence of TV, video, computer, and telephone formats. One thing is for sure, we are very likely to have more to read rather than less.

Guidance on medical use of the internet is available in a booklet by Pallen, ${ }^{6}$ which is a collection of articles reprinted from the $B M F$, and in the regular "Netlines" features which also appear in the BMF. Additional infor- mation for those interested in the issues raised here is available in a new bimonthy newsletter ( $\mathrm{He} @ 1$ lth Information on the internet) published by the Royal Society of Medicine in association with the Wellcome Trust.

B J CLARK

Department of Pathology, Institute of Ophthalmology, Bath Street, London EC1V 9EL

email: brian-clark@ucl.ac.uk

A member of the eyepathology email discussion group

1 Helman T, Wood G, MacFadyen D, et al. BMJ on the internet. BMF 1995;310:1674-5.

2 Jones R, Grainger F, Evans S, et al. The scandal of poor medical research. Sloppy use of literature often to blame. BMF 1994;308:591.

3 Sellu DP. A comprehensive bibliography database using a microcomputer. BMF 1986;292:1643-5.

4 Borer MJ, Hebert TE, Breshears D. Cost and demand analysis of excimer laser use: first world wide web internet survey of the interest in refractive surgery. $\mathcal{F}$ Cataract Refract Surg 1996;22:709-12.

5 Dick B, Eisenmann D, Tekaat CJ, et al. Ophthalmological information exchange of letters and digital pictures via the internet. Klin Monatsbl Augenheilkd 1996;209:aA7-15.

6 Pallen M. Guide to the internet. An introduction for healthcare professionals. 2nd ed. London: BMJ Books, 1998.

\section{Sources of bias in studies of optic disc and retinal nerve fibre layer morphology}

Interest in the morphology of the optic disc and nerve fibre layer in glaucoma has increased with the advent of new instruments able to make quantitative measurements of the optic disc and nerve fibre layer structure. Particular attention is given to the potential that these instruments may have to diagnose the condition(s) that we call glaucoma - that is, to classify individuals as "normal" or "glaucomatous".

The usual way in which we evaluate a test is to apply it to a "normal", reference, population and to a population believed to have the disease on the basis of other "gold standard" tests, and then count the proportions that are correctly classified in the two groups. In order to be able to generalise the results to clinical practice, the study population must reflect the population to which the test will be applied. Care, therefore, needs to be taken that restriction (entry) criteria applied to individuals do not bias the outcome. A frequent error is the use of an outcome variable of a test to restrict the entry of subjects into either the "normal" group or the "disease" group. In the context of glaucoma, we may want to know whether abnormal disc (or nerve fibre layer) morphology can correctly identify glaucoma patients. Restriction criteria should, therefore, not include optic disc appearance, but other gold standard tests, such as perimetry. Too often one finds a phrase such as "normal appearing optic disc" as a restriction criterion for the entry of subjects into a control group. Similarly, the phrase "optic disc cupping consistent with the diagnosis of glaucoma" is found as a restriction criterion for glaucomatous patients. The restrictions anticipate the outcome of the study, and make such studies impossible to evaluate. The results of such studies are merely a description of the groups selected to have a certain appearance of optic disc/ nerve fibre layer, not of what is "normal" or "abnormal". The findings cannot be extrapolated to the (unselected) general population.

To some extent, visual field restriction criteria may bias the findings of investigations into the pattern of glaucomatous morphological changes, because the topography of optic disc and visual field changes are likely to be related. Thus, selection of patients with "typical" glaucomatous field defects, such as the arcuate scotoma, will bias findings towards inferotemporal and superotemporal neuroretinal rim thinning. This bias is more difficult to avoid than that of direct selection on the basis of disc appearance. This is because glaucoma patients almost invariably come from the pool of clinic patients who have been "identified" as glaucomatous on the basis of currently recognisable signs. It may be difficult to overcome some of these biases, and these limitations should be recognised in the discussion of the results. Study designs that actively promote bias, such as the inclusion of optic disc morphology in the restriction criteria of studies investigating optic disc changes in glaucoma, should be avoided. Reviewers should ensure that the conclusions of such studies go no further than the study design allows.

D F GARWAY-HEATH R A HITCHINGS

Glaucoma Unit, Moorfields Eye Hospital, City Road, London EC1V 2PD 